\title{
Teaching Symmetry in the Light of Didactic Situations
}

\author{
Ezgi Selman ${ }^{1}$, Menekse Seden Tapan-Broutin ${ }^{2}$ \\ ${ }^{1}$ Mathematics Teacher, Yavuz Ersat Kabukcu College, Bursa, Turkey \\ ${ }^{2}$ Asst. Prof. Dr., Uludag University, Faculty of Education, Mathematics Education Department, Turkey \\ Correspondence: Menekse Seden Tapan-Broutin, Asst. Prof. Dr., Uludag University, Faculty of Education, Mathematics \\ Education Department, Turkey.
}

Received: November 1, 2018

doi:10.11114/jets.v6i11a.3811

\author{
Accepted: November 22, 2018 \\ Online Published: November 29, 2018 \\ URL: https://doi.org/10.11114/jets.v6i11a.3811
}

\begin{abstract}
The purpose of this study is to determine the student experiences for a lesson plan designed according to Didactic Situation Theory using Cabri-Geometry software. In line with this aim, we worked with four seventh grade students in Bursa. Within the scope of the study, students were given a black box activity involving the symmetry transformation made in the computer environment. Descriptive analysis of qualitative research methods was performed, and data were processed according to the thematic framework. The students were invited to do our black box activity. As a result they made some group discussions about their process of learning and discovering concepts and gave feedback on their experiences. All five phases of the Didactic Situations Theory have been exemplified in the findings of the study. The results showed that students could construct the concept of symmetry with its properties by means of the constructive environment prepared with the black-box activity.
\end{abstract}

Keywords: symmetry, didactic situation theory, Cabri-geometry, black-box activity

\section{Introduction}

Geometry is a branch of mathematics focusing on space, and shapes and figures that can be designed in space. When geometry is associated with daily life, transformation geometry stands out. Transformation geometry examines translations, reflections and rotations of shapes and develops the spatial intelligence of students. The concept of symmetry, which is very common from arts to architecture in daily life, is a concept observed even in early ages in children. The symmetry of animals and plants and other creatures in nature arouse the attraction of students (Bintaş, Altun and Arslan, 2003). Using these examples in mathematics lessons helps the students to develop positive attitude towards mathematics (Shaffer, 1997). Orton stated that acquiring the concept of symmetry provides a basis for transformation geometry activities which includes higher level skills (Orton, 1999, s.149). Moreover, learning the concept of symmetry in elementary school helps to understand mathematical concepts such as area and space better (Liebeck, 1984). The foundations of the symmetry concept are laid in the $1^{\text {st }}$ grade of elementary school through the congruence concept (MEB, 2009) Mistakes during the learning process of this concept, affect many learning experiences including problem solving. In our country, the concept of symmetry used to be identified as part of the achievements of $2^{\text {nd }}-8^{\text {th }}$ grades in the curriculum whereas now the current curriculum indicates it as achievements of $7^{\text {th }}$ and $8^{\text {th }}$ grades (MEB, 2013). Symmetry and translation units are thoroughly examined under the topic "transformation geometry" in the $7^{\text {th }}$ grade.

Various definitions of symmetry are available within the literature. Baki (1996) defines symmetry as preserving the distance to a location. According to Leikin, Berman and Zaslavsky (1997) symmetry is a transformation without altering the features of the shape. Based upon these two definitions; symmetry is a transformation, which can be defined as an injective and surjective function, converting every point on the plane again into points on the plane, while preserving the distance of each set of points (Zembat, 2007). While using pen and paper, students may experience difficulty in preserving the distance and locating the symmetry axis. This and similar reasons, and the complexity and novelty of transformation geometry introduced the use of dynamic geometry software programmes in teaching geometry (Yavuz, 2013). Some research concluded that without using dynamic geometry software students have difficulty with reflection over a diagonal line and that they cannot fully comprehend the subject (Küchemann,1981; Grenier,1987). Cabri -Geometry is one of the dynamic geometry softwares that develop mathematical thinking of students through its tools. It enables studying situations that are hard to detect and create by only using pen and paper. 
Cabri's special features allow us to analyze geometry dynamically (Baki, 2001). Another advantage of this programme is that it does not require any pre-knowledge and all subjects of transformation geometry can be studied with it (Güven and Karataş, 2003).

The key to provide improvement in teaching mathematics is to know how individuals learn mathematics (Skemp, 1986). Therefore, Brousseau's Theory of Didactical Situations is one of the theories used in mathematics education.

\section{Theory of Didactical Situations}

The Theory of Didactical Situtations (Brousseau, 1997), based on the constructivist approach, gives the opportunity to the students to form their own knowledge within the mathematics education environment. From this aspect, the basis of the theory is formed by adidactical situations. This refers to the learning context that the teacher consciously designs to enable the learning process (Sensevy et al., 2005). The environment in the theory comprises the interaction of the student and the "milieu" (Brousseau, 2002). Environments used in adidactical situations are adidactical as well. The student's interaction with the information source is more important than the student's communication with the teacher. The aim of the theory is that the student explores and structuralizes the information on his/her own (Laborde and Perrin-Glorian, 2005). It is essential that adidactical environments are designed in such a way that students can receive positive or negative feedback (Brousseau, 2002; Erdoğan, 2016). Therefore, each activity for adidactical environments should be selected meticulously (Erdoğan and Özdemir Erdoğan, 2013; Erdoğan, 2016).

On one hand activities or problems designed for adidactical environments should include a starting point on which students can reason, on the other hand they should comprise characteristics that the students can not immediately identify when facing the problem. Once the student gets integrated to the designed environment, he/she can reach the information and reveal the solution (Bessot, 1994; Brousseau, 2002; Erdoğan, 2016).

Brousseau $(1997,2002)$ presented an education process where the didactical situation comprises 5 phases: The first phase is devolution. The teacher should ensure that the students understand and grasp the activity and are ready to take responsibility about the subject by providing a suitable environment. In the second phase, referred to as action, students attempt to solve the problem and reach some conclusions regarding the solution. The third phase is formulation. Students are expected at this phase to explain the results they achieved in the previous phase. It is unknown to which extend these explanations are correct. The fourth phase is validation. This is the phase where the results the students reached are evaluated with the participation of the whole class. This evaluation leads either to approval or rejection of the results. These phases provide the targeted information. However, this information lacks institutional value. Therefore, the last phase institutionalization is where the teacher repeats the results and revealed information in detail and institutionalizes them by employing proper terminology.

Action, formulation and validation are adidactical phases in which the teacher's duty is to plan the interactions within and among groups and to confront the students with the parameters of the environment. This is how the teacher's influence is minimised on developing, selecting and proving solutions regarding the gained knowledge, thus enabling students to act on their own (Erdoğan, 2016).

The most essential matter in the Theory of Didactical Situations is the shared activities of the students and teachers. (Sensevy and Mercier, 2007). In this theory, it is emphasized to create a class environment where students act like scientists, research, discover and produce. The classroom-environment-creating approach, explained in this research, is deemed to be effective in teaching symmetry within transformation geometry and to improve spatial thinking skills in students.

Literature contains many studies emphasizing the importance of Cabri, Gebra and other dynamic software programmes in geometry education. One of these is the study "Teaching Reflection and Translation with Cabri” by Bütüner (2010). Cabri was used to prepare study papers appropriate for discovery learning. The paper was not implemented. It was designed with the purpose of showing an example for the teachers. A similar applied study is Çetin, Erdoğan and Yazlık (2015) “The Effect of Using Geogebra Software on Students' Achievement of Transformation Geometry". The research was carried out to compare the learning level regarding transformation geometry of eighth grade students in mathematics with Geogebra software assisted activities based on 5E model and with the help of paper folding-cutting and material aided activities in course books. The research was conducted with test and control groups. The results showed that lectures prepared with Geogebra increase student achievement more than lectures aided by paper folding-cutting and materials. Studies (Baydaş, Göktaş and Tatar, 2013; Doğan and İçel, 2011; Güven and Yılmaz, 2011; Selçik and Bilgici, 2011; Şataf, 2009; Yavuzsoy-Köse and Özdaş, 2009; Yazlik and Ardahan, 2012) within the literature support this result. Moreover, the Theory of Didactical Situations has an applied study on another subject. This study of Mustafa Gök and Abdulkadir Erdoğan (2017) is called "Non-routine Mathematical Problem Solving in Classroom Environment: An Example Based upon the Theory of Didactical Situations". Students were directed a problem in this study and their solutions were analysed with the steps specified by the theory. The results indicated that the Theory of 
Didactical Situations can be used as an effective tool in problem solving. Turkish resources lack studies on applying the theory effectively in classroom environment when teaching transformation geometry. This study analyses both student experience resulted by applying Cabri and the theory. The teacher serves both as a researcher and implementer. This study stands out in terms of including both situations and performing application. It is considered to improve the literature as it will provide a new point of view.

In this context, the purpose of this study is to determine the student experiences for a lesson plan designed according to Didactic Situation Theory using Cabri-Geometry software

Problem statement:

What are the experiences the students have through learning Cabri-Geometry based symmetry and translation units designed according to the Theory of Didactical Situations for $7^{\text {th }}$ graders?

\section{Method}

\section{Method of the research}

Qualitative research methods were employed in this research. This method allows the researchers to work with small groups, but therefore to gain in-depth information, understanding and wider insight on the specified subjects (Patton, 1990; Yıldırım ve Şimşek, 2008). This is not an intervention study. This research, conducted to identify student experience in a created learning environment, is designed as a case study. In a case study the researcher tries to understand one situation in great depth; a particular individual, programme, phenomenon or event is studied in depth for a defined period of time. The case is limited with time and the event, and researchers gather detailed data by using various data collection methods over a long period of time (Stake, 1995; Yin, 2009, 2012).

\section{Participants}

The study was conducted in the first semester of the 2017-2018 academic year in a public secondary school in northwest Turkey. The study group of the research consists of four female $7^{\text {th }}$ grade students. The students were selected with the recommendation of the mathematics teacher among successful students based on voluntariness. The participants had previously observed activities in maths lessons regarding Cabri-Geometry software use and had minor knowledge on using the software themselves.

\section{Procedure}

First of all, a lesson plan, appropriate for $7^{\text {th }}$ grade achievements and where the phases of the Theory of Didactical Situations can be easily observed, was designed. This plan includes a black box activity conducted with Cabri-Geometry programme. The purpose of the activity is that the students realize the symmetry transformation on their own after they apply a few steps correctly. The a priori analysis of the activity was conducted to determine possible student strategies and didactical variables. The activity and its a priori analysis were presented to two expert academics and a mathematics teacher to improve the activity with the help of their suggestions. Before applying the real activity a test study was done with two students who know to operate Cabri-Geometry. The results of this test study helped to eliminate any existing mistakes and to give the activity its final form. Since the students knew little about the programme, two hours of training about Cabri-Geometry programme and instructions how to use it was given to the students prior to the application. After the training, the lesson plan was put into practice. The students were divided into groups of two and the researcher did not assist them in any way except for technical problems regarding the computers. The teacher introduced the activity in the beginning of the class and devolved the responsibility to the students. The activity continued for two lessons.

\section{Data collection tools}

Data collection tools in the research were; in-class observations, observation notes, video recordings of the activity and screen recordings of participants. During the data collection process, the students were observed doing the activity and notes were taken. Besides that, during the entire activity the students and their computer screens were recorded. The video recordings were transcribed with regards to the notes and screen recordings and analysed.

\section{Analysis techniques}

The data obtained is analysed in terms of descriptive analysis. In descriptive analysis all provided data is summarised and interpreted according to predetermined themes. Direct quotations are frequently used to objectively reflect the experiences of the observed individuals (Yildirim and Simsek, 2005). Data of this study is analysed conforming to the phases of the Theory of Didactical Situations. These phases are; Devolution, Action, Formulation, Validation and Institutionalisation. During presentation of the findings, the experiences of each phase were exhibited through direct quotations. Actual names of the students were not mentioned in these quotations; each student was given a number such as Student 1, Student 2, and Student 3etc. 


\section{Reliability and validity}

Reliability in qualitative research depends on the researcher's objectivity and him/her making explanations according to the theoretical structure (Büyüköztürk et al., 2012). Reliability in this study was ensured by following the selected theoretical framework strictly and presenting direct quotations of the students. In addition to that reliability and validity were increased by decreasing anxiety levels of the students through informing them on the activity, indicating that their academic success will not be affected and guaranteeing them to be kept anonymous.

\section{Findings}

The findings of the activity were organized separately for each phase of the theory and are presented below:

\section{Devolution Phase}

This phase started with the researcher explaining the purpose of the activity.

Researcher:[...] We will do an activity together. The activity is called "Surprise Transformation". You will find how the given shape was formed. I will explain the steps and you will apply them. You are not allowed to ask me questions. You will come to a conclusion on your own by following the steps on the computer. I can only help if you have a technical problem with the computer.

These words expressed how the researcher was going to behave during the activity and what he/she expected the students to do. The researcher then divided four students into two groups of two and asked them to open the Cabri-Geometry programme on the computer. The macro construction needed for the activity was added to the computers by the teacher prior to the application. Once everyone was ready, the teacher read the steps of the activity out loud. The shape created after the last step surprised and confused the students. This phase ended by applying the steps of the macro construction. The screen view of the shape created through the macro construction is given in Figure 1.
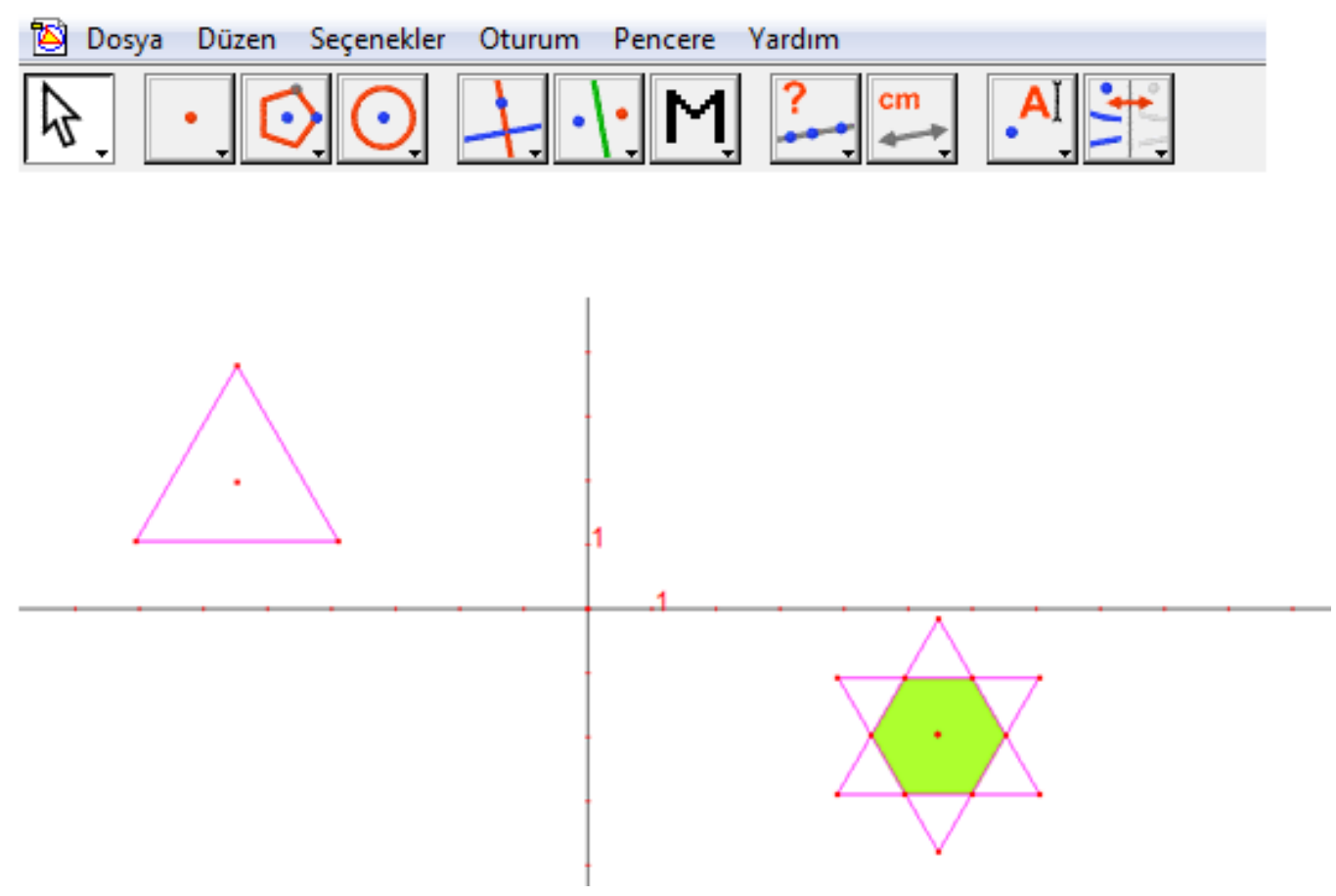

Figure 1. Surprise macro construction screen view

\section{Action Phase}

The action phase started after the researcher formed the groups and left the responsibility to the students. The sentence of the researcher starting the action phase is given below:

Researcher: Now a shape is formed. How was this shape formed? You need to discuss it. First discuss it within your group, then altogether.

In the action phase, the students tried to comprehend the shape with their group members. The dialogue of Group 1 at the beginning of the phase is given below: 
Student 1: Let's open a new page and draw the triangle. (They click the macro again. The surprise shape appears.)

Student 2: There is a straight and a reverse triangle. Did this appear by the common points?

Student 1: Is it OK if we created a new triangle and put the same on it?

Researcher: I don't know. You must try.

In the action phase the students tended to get approval from the researcher before they applied their own strategy. Both groups expressed they needed to find the symmetry but could not easily decide where to start. Both groups first drew a reverse triangle with their hands on the given triangle. Then they realised that although the triangle they drew was similar to the given triangle, their sides were not equal. The dialogues that took place right afterwards is given below:

Student 1: OK now let's take this down. Come to the symmetry according to the point. Click on the triangle. Now click on this (origin). We moved the triangle. Student 2: Let's take the point. I'm doing the same thing. OK.

Student 1: Now let's draw a reverse triangle on it.

Student 2: From the regular polygon?

Student 1: Yes

Student 2: Oooooh right we got it. But the sides don't seem to be even.

Student 1: Let's open a new page.

The students hypothesized that the image shape can be obtained by using the symmetry tool. However, the two groups differed in terms of which axis to use to find the symmetry. Group 2 found the symmetry first from y-axis then from $\mathrm{x}$-axis. They considered the point inside the triangles as a separate unit and attempted to find the symmetry of this point according to origin. The related dialogue is presented below:

Student 4: We first clicked here (showing the triangle they drew). Yes this appeared.

Student 3: Yes.

Student 4: Now we will take it according to X. Done.

Student 3: Now we will try to take this point there (showing the point in the middle of the triangle they first drew. Finds the symmetry of the point according to the origin and carries it over to area 4)

The most frequent mistake students made in this phase was that the place where they wanted to find the symmetry and the tab they clicked were different. They were unaware doing this, yet this mistake prevented them from finding the right result and they could not find the reason. This situation is rather due to their habits of using the programme than a lack of mathematical knowledge. The action phase was the longest as the students did a lot of trial and error.

\section{Formulation Phase:}

The researcher's sentence starting this phase is given below:

Researcher: Everyone has to explain the results they obtained clearly. So think thoroughly with your partner.

In the formulation phase, the students contemplated the ideas they formed in the previous phase with their reasons. In addition to that they kept on doing new trials. They tried to explain their hypotheses they constructed and tested in the previous phase. This phase was more challenging for group 2 who did not use a particular mathematical property consciously but relied heavily on trial and error method. Students constructed sentences with informal words in this phase. The dialogue of group 2 assessed in this phase is given below:

Student 4: Actually we did well. Draw the triangle again. Let's work from this triangle (finding the symmetry by clicking on the edges of the triangle and the point in the middle of it.). We will draw the triangle again. As a line segment. (They draw the triangle by connecting the points.)

Student 3: Yes this one is equal. We created the thing of the triangle by finding the symmetry of this point (an edge of the triangle in area 4) according to this point (the point inside that triangle).

Student 4: So...

Student 3: So of this point. 
Students noticed their mistakes while trying to explain the results and made further trials. Besides that they continuously tried to prove their findings. Therefore, this phase, the previous action phase and the following validation phase were intertwined.

\section{Validation Phase:}

Groups first convinced each other in this phase then explained the results they reached after getting the approval of the researcher. Researcher's statement starting this phase is given below:

Researcher: Everyone got their results. Each group has formed their triangles in a different way. Now get together and tell each other how you worked. Talk to each other. Open a new page and show.

These sentences initiated the validation phase and the groups gathered around one computer to explain each other what they did. Both solution methods were approved by the two groups. Below you can find a sample conversation of a group member explaining their solution to the other group:

Student 1: We first took the axes from here. We drew our triangle. Then we first clicked on the symmetry according to the point. We first clicked this point (inside the triangle) then clicked the origin and moved the point. We then clicked the symmetry according to the point and clicked this time on the side of the triangle and created the triangle again. This time we clicked the point inside the triangle and its side. The same appeared.

\section{Institutionalisation Phase:}

In this phase the researcher restated the correct solution strategies which were presented by the students and approved by the groups. The possibility of creating the same shape with two different methods was emphasized. The researcher then mentioned regarding the new shape that a hexagon appeared in the middle and that its sides were equal. Besides that it was expressed that symmetry was taken according to different points but the resulting shape was the same. The original shape and the symmetry were matching; the size and shape were the same, just the location and direction were different.

\section{Results, Conclusions and Recommendations}

In this study student experiences were investigated resulting from applying an activity about symmetry, which is a topic of transformation geometry, based on the phases of the Theory of Didactical Situations conducted with Cabri-Geometry in a classroom environment. An adidactical setting was designed in compliance with the constructivist approach. The black box activity was designed by the researcher. It was significant that this black box activity was both surprising and intriguing for the students. As a matter of fact - supporting these results - Baki (2001) states that the unique features of Cabri-Geometry allow students to study geometry dynamically.

This research is based on an activity designed using the Theory of Didactical Situations. In the first phase, the teacher fully devolved research and learning responsibility to the students. As the students were not accustomed to this situation, they had difficulties accepting and kept on looking for approval from the teacher. The action phase was the longest which also included formulation and validation phases. The students tried all their ideas on computers and tried to reach the solution. The students did many trials in this phase and had the opportunity to apply their ideas. The formulation phase was the hardest. The students tried to explain their actions with informal words and had difficulties with terminology. The students used verbal expressions very similar to Hoyles and Healy's (1997) research findings such as "harmony", "reflection", "looking similar to each other", "reverse" which is an indication of their awareness. This result has resemblance with the findings of Bintaş, Altun and Arslan (2003) where they stated that the students were aware of the symmetry of the given shape and that they expressed it with informal words. In the validation phase, students explained each other their methods and proved what they did was correct. In the institutionalisation phase, the teacher rephrased the statements of the students with proper mathematics terminology. As a result, the Theory of Didactical Situations has proven to be an efficient theoretical tool in teaching symmetry.

Based upon the study results, it can be beneficial to design activities using the Theory of Didactical Situations and to conduct research on applying these activities. In addition to that it is important to introduce black box activities to teachers and thus giving a new perspective to mathematics education by enabling discovery learning.

\section{References}

Baki, A. (1996). Matematik öğretiminde bilgisayar herşey midir? Hacettepe Üniversitesi Eğitim Fakültesi Dergisi, 12, 135-143.

Baki, A. (2001). Bilişim Teknolojisi Işı̆̆ı Altında Matematik Eğitiminin Değerlendirilmesi, Milli Eğitim Dergisi. 149, 26-31. 
Baydaş, Ö., Göktaş, Y., \& Tatar, E. (2013). Farklı Bakış Açılarıyla Matematik Öğretiminde Geogebra Kullanımı. Çukurova University Faculty of Education Journal, 42(2), 36-50

Bessot, A. (1994). Panorama del quadro teorico della didactica matematica. L'Educazione Matematica, 15(4).

Bintaş, J., Altun, M., \& Arslan, K. (2003). Gerçekçi matematik eğitimi ile simetri öğretimi. Matematikçiler Derneği, http://www.matder.org.tr/index.php?option=com_content\&view=article\&catid=8:matematik-kosesi-makaleleri\&id $=57:$ simetri-ogretimi\&Itemid $=38$ accessed in March 22, 2018.

Brousseau, G. (1997). Theory of didactical situations in mathematics. Dordrecht: Kluwer Academic Publisher.

Brousseau, G. (2002). Theory of Didactical Situations In Mathematics. London: Kluwer Academic Publisher.

Bütüner, S. Ö. (2010). Dinamik Geometri Yazılımlarından Cabri ile Yansıma ve Öteleme Hareketlerinin Öğretimi.Elementary Education Online , 9(2), 6-10.

Büyüköztürk, Ş., Kılıç, Ç. E., Akgün, Ö. E., Karadeniz, Ş., \& Demirel, F. (2012). Bilimsel araştırma yöntemleri (11.Bask1). Ankara: Pegem Akademi

Çetin, İ., Erdoğan, A., \& Yazlık, D. Ö. (2015). Geogebra ile Öğretimin Sekizinci Sınıf Öğrencilerinin Dönüşüm Geometrisi Konusundaki Başarılarına Etkisi. Uluslararası Türk Eğitim Bilimleri Dergisi , 2015(4), 84-92.

Doğan, M., \& İçel, R. (2011). The role of dynamic geometry software in the process of learning: GeoGebra example about triangles. International Journal of Human Sciences, 8(1), 1442-1458.

Erdoğan, A., \& Özdemir, E. E. (2013). Didaktik Durumlar Teorisi Işı̆̆ında İlköğretim Öğrencilerine Matematiksel Süreçlerin Yaşatılması. Ahi Evran Üniversitesi Kırşehir Eğitim Fakültesi Dergisi (KEFAD), 14(1), 17-34.

Gök, M., \& Erdoğan, A. (2017). Sınıf Ortamında Rutin Olmayan Bir Matematik Problemi Çözme:Didaktik Durumlar Teorisine Dayalı Bir Uygulama Örneği. Yüzüncü Yll Üniversitesi Eğitim Fakültesi Dergisi , 14(1), 140-181.

Grenier, D. (1987). The pupils' conception on axial symmetry: An individual activity. Paper presented at the meeting of 11th International Conference for the Psychology of Mathematics Education, Montreal, Canada.

Güven, B., \& Yılmaz, K. G. (2011). Dinamik Geometri Yazılımlarının Dönüşüm Geometrisi Konusunda Sınıf Öğretmeni Adaylarının Başarılarına Etkisi. 5th International Computer Instructional Technologies Symposium, Gaziantep.

Güven, B., \& Karataş, I. (2003). Dinamik Geometri Yazilimi Cabri ile Geometri Ögrenme: Ögrenci Görüsleri. TOJET: The Turkish Online Journal of Educational Technology, 2(2).

Hoyles, C., \& Healy, L. (1997). Unfolding meanings for reflective symmetry. International Journal of Computers for Mathematical Learning, 2, 27-59. https://doi.org/10.1023/A:1009721414546

Köse, N. Y., \& Özdaş, A. (2009). İlköğretim 5. Sınıf Öğrencileri Geometrik Şekillerdeki Simetri Doğrularını Cabri Geometri Yazılımı Yardımıyla Nasıl Belirliyorlar? Illköğretim Online , 8(1), 159-175.

Küchemann D. (1981). Reflection and Rotation. In Hart K (Ed.) Children's understanding of mathematics (pp. 137-157). London: John Murray

Laborde, C., \& Perrin-Glorian, M. J. (2005). Introduction teaching situations as object of research: Empirical studies within theoretical perspectives. Educational Studies in Mathematics, 59, 1-12. https://doi.org/10.1007/s10649-005-5761-1

Leikin B., Berman A., \& Zaslavsky O. (1997). Defining and understanding symmetry. In E. Pehkonen (Ed.), Procedding of PME, 21(3), 192-199.

Liebeck, P. (1984). How children learn mathematics. A guide for parents and teachers. England: Penguin Books.

Milli Eğitim Bakanlığı [MEB]. (2009). İlköğretim matematik dersi 1-5. Sinfflar öğretim programı. Ankara: Talim ve Terbiye Kurulu Başkanlığı.

Milli Eğitim Bakanlığı [MEB]. (2013). İlköğretim matematik dersi 5-8. Sinfflar öğretim programı. Ankara: Talim ve Terbiye Kurulu Başkanlığı.

Orton, J. (1999). Children's perception of pattern in relation to shape. In A. Orton (Ed.), Pattern in the teaching and learning of maths. (pp. 149-167). London: Cassell.

Patton, M. Q. (1990). Qualitative evaluation and research methods (2nd Edt.). Newbury Park, CA: Sage.

Şataf, H. A. (2009). Bilgisayar Destekli Matematik Öğretiminin İlköğretim 8. Sinı Öğrencilerinin Dönüs̆üm Geometrisi ve Üçgenler Alt Öğrenme Alanındaki Başarısı ve Tutuma Etkisi. Yüksek Lisans Tezi, Sakarya Üniversitesi, Sosyal 
Bilimler Enstitüsü, Bilgisayar ve Öğretim Teknolojileri Eğitimi Anabilim Dalı, Sakarya.

Selçik, N., \& Bilgici, G. (2011). Geo-Gebra yazılımının öğrenci başarısına etkisi. Kastamonu Eğitim Dergisi, 19(3), 913-924.

Sensevy, G., \& Mercier, A. [eds] (2007) Agir ensemble. L'action didactique conjointe du professeur et des élèves. Presses universitaires de Rennes.

Sensevy, G., Schubauer-Leoni, M. L., Mercier, A., Ligozat, F., \& Perrot, G. (2005). An attempt to model the teacher's action in the mathematics class. In C. Laborde, M.- J. Perrin-Glorian \& A. Sierpinska (Eds.), Beyond the apparent banality of the mathematics classroom (pp. 153-181), Springer. https://doi.org/10.1007/0-387-30451-7_6

Shaffer, D. W. (1997). Learning mathematics through design: The anatomy of Escher's world. The Journal of Mathematical Behavior. 16(2). 95- 112 https://doi.org/10.1016/S0732-3123(97)90019-5

Skemp, R. (1986). The pschology of learning Mathematics. London: Penguin Books Ltd.

Stake, R. E. (1995). The art of case study research. Thousand Oaks, CA: Sage.

Yavuz, İ. (2013). Cabri Geometri ile Geometri Öğretimi, (Eds. M. Doğan, \& E. Karakırık). Matematik Eğitiminde Tekoloji Kullanımı(pp.197-234), Nobel Yayınları:Ankara.

Yazlik, D. O., \& Ardahan, H. (2012). Teaching Transformation Geometry with Cabri Geometry Plus II. Procedia Social and Behavioral Sciences, 46, 5187-5191. https://doi.org/10.1016/j.sbspro.2012.06.406

Yıldırım, A., \& Şimşek, H. (2005). Sosyal bilimlerde nitel araştırma yöntemleri. Ankara: Seçkin Yayınları

Yıldırım, A., \& Şimşek, H. (2008). Sosyal bilimlerde nitel araştırma yöntemleri (6. baskı). Ankara: Seçkin Yayıncılık.

Yin, R. K. (2009). Case study research: Design and methods (4th ed). Thousand Oaks, CA: Sage.

Yin, R. K. (2012). Applications of case study research (3rd ed). Thousand Oaks, CA: Sage.

Zembat, İ. Ö. (2007). Yansıma Dönüşümü, Doğrudan Öğretim ve Yapılandırmacılığın Temel Bileşenleri. Gazi Eğitim $\begin{array}{lllll}\text { Fakültesi Dergisi, 27(1), 195-213. } & \text { [Online] }\end{array}$ http://gefad.gazi.edu.tr/article/view/5000078650/5000072871 in March 13, 2018.

\section{Copyrights}

Copyright for this article is retained by the author(s), with first publication rights granted to the journal.

This is an open-access article distributed under the terms and conditions of the Creative Commons Attribution license which permits unrestricted use, distribution, and reproduction in any medium, provided the original work is properly cited. 